Vol. 15, $n^{\circ} 1 \mid 2011$

Varia

Musin Aude, Xavier Rousseaux, Frédéric Vesentini (eds), Violence, conciliation et répression. Recherches sur l'histoire du crime de l'Antiquité au XXI siècle Louvain-la-Neuve, Presses Universitaires de Louvain, 2008, 326 pp., ISBN 9782874631337.

\title{
Pieter Spierenburg
}

\section{(2) OpenEdition}

\section{Journals}

Electronic version

URL: https://journals.openedition.org/chs/1252

DOI: $10.4000 /$ chs. 1252

ISSN: 1663-4837

Publisher

Librairie Droz

Printed version

Date of publication: 1 May 2011

Number of pages: 135-136

ISBN: 978-2-600-01515-8

ISSN: $1422-0857$

\section{Electronic reference}

Pieter Spierenburg, "Musin Aude, Xavier Rousseaux, Frédéric Vesentini (eds), Violence, conciliation et répression. Recherches sur I'histoire du crime de l'Antiquité au XXIe siècle", Crime, Histoire \& Sociétés I Crime, History \& Societies [Online], Vol. 15, $n^{\circ} 1$ | 2011, Online since 06 March 2013, connection on 23 March 2022. URL: http://journals.openedition.org/chs/1252 ; DOI: https://doi.org/10.4000/chs. 1252

This text was automatically generated on 23 March 2022.

(C) Droz 


\section{Musin Aude, Xavier Rousseaux, Frédéric Vesentini (eds), Violence, conciliation et répression. Recherches sur l'histoire du crime de l'Antiquité au $\mathrm{XXI}^{e}$ siècle}

Louvain-la-Neuve, Presses Universitaires de Louvain, 2008, 326 pp., ISBN 9782874631337.

Pieter Spierenburg

\section{REFERENCES}

Musin Aude, Xavier Rousseaux, Frédéric Vesentini (eds), Violence, conciliation et répression. Recherches sur l'histoire du crime de l'Antiquité au XXI ${ }^{e}$ siècle, Louvain-la-Neuve, Presses Universitaires de Louvain, 2008, 326 pp.,

ISBN 9782874631337.

1 This collection is announced as the first volume in a series on «history, justice and societies» of the University of Louvain Press. Of the three editors, apart from the very brief introduction, it is only Rousseaux who is present with a contribution of his own. Although the volume's title is given exclusively in French, some of the contributions are in Flemish or Dutch. As the title indicates, they cover a wide area within the field of crime and justice history with respect to both chronology and subject. They also vary in quality. It seems best, therefore, to say a few words about each contribution separately. Because of the bilingualism, I will give their titles in English.

2 Julien Maquet, 'Hagiographical sources and the exercise of justice in the middle ages, $10^{\text {th }}-12^{\text {th }}$ centuries' (9 pp.) explores some narratives of saints' lives for passages dealing 
with judicial practices, concluding that this type of source can be profitably used for that purpose.

3 Frédéric Lalière, 'The pardon letter as a source, direct and indirect: A juridical instrument in the centralization of power and a promising field for the legal historian' (45 pp.) discusses pardon letters from Hainaut and Namur in the fifteenth century. These letters appear to have had the same function and structure as in other Burgundian and French territories at the time.

4 Marjan Vrolijk, 'Reconciling and correcting in the sixteenth century: The case of Van Muelenbeke vs. De Goudsmet' (24 pp.) discusses feuding, reconciliation and justice in sixteenth-century Flanders, taking one conflict as an example.

5 Éric Maes, 'The legal regulation of the prison régime in Belgium: Developments regarding the practice of detention over two centuries, 1795-present' (45 pp.) discusses changes in legal provisions with respect to prisoners' rights. The author uses naïve terms such as improvement and ignores my warning (in The Prison Experience, 1991) not to refer to the unreliable writings of the amateur historian A. Hallema.

Guy Dupont, 'Age profiles of perpetrators and victims in the late middle ages: How can historians make silent sources speak?' (15 pp.) has an interesting method for determining a person's approximate age from the first name suffix, but the author admits that he has published about this before (which had eluded the present reviewer).

7 Mariann Naessens, 'Sexual offenses in late-medieval Ghent: The limits of a quantitative approach to sources' (35 pp.) discusses prostitution, adultery and sodomy.

8 Anne van Cauwenberghe, 'The criminalization of women and penal repression in the accounts of the provost of Bastogne in the sixteenth century' (30 pp.) discusses all offenses with female perpetrators, in particular witchcraft and infanticide.

9 Nicolas Coupin, 'An aspect of order maintenance in Belgium: The expulsion of foreigners, 1830-1914' (19 pp.) establishes that the overwhelming majority were expelled for having no means of existence; the author fails to tell us to which countries they were expelled.

10 Françoise van Haeperen, 'Human sacrifices and ritual killings in Rome: Some observations' (20 pp.) establishes that, although some of the stories about these practices were propaganda, there have been several human sacrifices during moments of crisis in Republican times.

11 Xavier Rousseaux, 'Violence in pre-modern societies, sources, methods and interpretations: Nivelles, a city in Brabant during five centuries' (36 pp.) deals with the period 1378-1795 and focuses on the transformation from a mediating to a repressive system of justice which came about by the mid-sixteenth century.

12 Benoît Garnot, 'Violence in early-modern France: violence tamed?' (9 pp.) begins with a skeptical remark about the theories of Norbert Elias; has three references and concludes that early-modern Frenchmen also engaged in other activities besides violence.

13 Jean-Claude Farcy, 'Violence and the historians: France in the contemporary era' (25 pp.) provides a useful overview of the recent French historiography on the subject as well as a discussion of the various types of sources. The expression «contemporary era» 
is still used by the French to designate all history since 1789, so it now stretches over four centuries.

\section{AUTHORS}

\section{PIETER SPIERENBURG}

Erasmus University Rotterdam

spierenburg@law.eur.nl 